TIBOR SIPOS, Ph.D. ${ }^{1}$

(Corresponding author)

E-mail: sipos.tibor@mail.bme.hu

ZSOMBOR SZABÓ, Ph.D. student ${ }^{1}$

E-mail: szabo.zsombor@mail.bme.hu

ÁRPÁD TÖRÖK, Ph.D. ${ }^{2}$

E-mail: arpad.torok@gjt.bme.hu

${ }^{1}$ Budapest University of Technology and Economics

Faculty of Transportation Engineering and Vehicle

Engineering

Department of Transport Technology and Economics

Múegyetem rakpart 3, H-1111

Budapest, Hungary

${ }^{2}$ Budapest University of Technology and Economics

Faculty of Transportation Engineering and Vehicle

Engineering, Department of Automotive Technologies

Mủegyetem rakpart 3, H-1111 Budapest, Hungary
Traffic Management Original Scientific Paper Submitted: 12 June 2020 Accepted: 6 Nov. 2020

\title{
SPATIAL ECONOMETRIC CROSS-BORDER TRAFFIC ANALYSIS FOR PASSENGER CARS - HUNGARIAN EXPERIENCE
}

\section{ABSTRACT}

The role of cross-border commuting needs is remarkable, given that large cross-border cities tend to have high traffic attractiveness. Thus, agglomeration effects are strongly prevalent in populous settlements close to the border. This is due to the fact that both Hungary and the neighboring countries are burdened by spatial inequalities; therefore, the traffic at the individual border crossing points is unbalanced. Our aim is to show the extent to which the introduction of certain public transport modes contributes to the reduction of cross-border passenger car traffic. In order to do this, we have to set up a spatial econometric model that can simultaneously handle the parallel public transport infrastructure, the cross-border attractiveness of border cities, and the impact of spatial inequalities. The results of the research shed light on how the introduction of each means of transport contributes to increasing the competitiveness of border regions. This will demonstrate the effectiveness of policy tools that can improve the competitiveness of a given macroregion.

\section{KEYWORDS}

transportation geography; spatial econometrics; separation effect; cross-border traffic.

\section{INTRODUCTION}

The borders of a country cause spatial separation, which has some effects on everyday life through the transportation network. Most border regions in Hungary, and in other countries as well, suffer from worse life quality, which is caused by the closeness of the border. The distribution of border crossing points affects the technological characteristics of the available network, and the public transport system as well. In this paper the main goal is to understand how the properties of the micro and macro region affect cross border passenger car flow, which is mainly generated by cross-border commuting. By examining the effect of the public transportation network and lines, the existence of the micro regional centers, and the spatial inequality on the cross-border traffic volume, a scientific tool can be given to the policymakers to help them decide where to improve the cross-border infrastructure for better international relations

In the authors' previous studies, it has been proved that cross-border traffic, and the separation effect - legal or physical severance between two regions (e.g. because of a border or a river) - can be efficiently analyzed through spatial econometric modelling. Spatial econometric models for aggregated traffic [1] and heavy goods vehicles (HGV) [2] were presented and the results verified the assumption that clustering traffic according to the types of vehicles gives better results. In this paper, a model specialized for passenger cars is developed and presented as the next step of cross border traffic analysis [3]. 
Analyzing the literature, econometric models are widely used in the field of cross-border traffic estimation $[4,5]$. Basically, two directions could be identified: the American models and the European ones. In case of the American modelling, the most important question is whether the restrictions after 9/11 terror attacks have a negative effect on the bilateral connections with the neighboring countries (e.g. [6, 7]) or not [8]. So, there are numerous models analyzing the Canadian [6, 9-11] and the Mexican [12] borders. Contrarily to the above, European researchers tend to focus on the positive effects of interrelationships [13-15].

Investigating certain transportation related research problems by spatial econometric methods promises a lot of new scientific possibilities. Spatial econometrics can be used to improve regression models. If spatial autocorrelation can be found, as it is tested by the Moran-I test [16], the classic OLS (Ordinary Least Squares) models contain errors because of not taking spatial dependence into consideration. The distinctive feature of our model is that this model takes into account the effects of spatial dependence, and instead of using a sample as e.g. [8, 17], it analyses all border crossings, which cannot be found in other papers. In transportation sciences one of the first articles to introduce spatial interaction is [18]. The spatial econometric analysis of different routes through a given territory was introduced by James P. LeSage and his co-authors through numerous articles and a book [19-21]. In this article, the spatial econometric framework is used instead the classic four step modelling, similarly to $[22,23]$.

\section{METHODOLOGY}

The applied methodology is mostly based on the research of Luc Anselin [24] and Attila Varga [25]. The main idea behind the applied model environment is built on the phenomena that traditional linear regression models estimated by ordinary least squares methods cannot take into consideration the fact that panel data based upon spatial specifications is not independent from its spatial location [24]. This means, where spatial autocorrelation can be found in the linear regression errors, those models cannot be used for further investigation; instead, a spatial econometric model ought to be used.
This spatial econometric analysis follows the methodology described by [26]. The first step is to set up the OLS models with proper explanatory variables. The set of decision variables is introduced in the next chapter.

The second step is the definition of the weight matrices (Table 1). In accordance with the methodology proposed in the literature, binary (B) and distance-based weight matrices (W) have been applied in our research. In the case of binary matrices, the spatial units have an effect on each other, depending on whether they share a common point (1) or not (0). In the case of distance-based matrices, the extent of dependency is based upon the distance between the spatial units. A detailed description of this method can be found in [24-27]. Eight weight matrices are constructed, which are denoted by an additional number (0-7). The models are distinguished based on the type of the resistance, whether it is distance (W) or binary (B) based, and the type of the assignment. Five types of assignments are distinguished:

- All: all of the border crossings have an effect on each other

- Neighbor: only the neighboring border crossings influence each other

- Main road: only those border crossings influence each other which are between two border crossings with a $2^{\text {nd }}$ class or higher road type

- Country: only those border crossings that connect the same two countries influence each other (e.g. all border crossings that connect Slovakia and Hungary influence each other)

- Transit: same as the main road, but the elements of the transit network have effects on each other. Thus, the border crossings should be divided into two groups: the first group contains the major border crossings, which can be used by HGVs above 3.5 tons and belong to main national or high-speed roads. The other group consists of the minor crossings. The assignment is the

Table 1 - Properties of weight matrices

\begin{tabular}{|c|c|c||}
\hline & Type of Matrix & Assignment \\
\hline \hline 0. matrix & $\mathrm{W}$ & All \\
\hline 1. matrix & $\mathrm{W}$ & Neighbor \\
\hline 2. matrix & $\mathrm{W}$ & Main Road \\
\hline 3. matrix & $\mathrm{B}$ & Country \\
\hline 4. matrix & $\mathrm{W}$ & Country \\
\hline 5. matrix & $\mathrm{B}$ & Main Road \\
\hline 6. matrix & $\mathrm{W}$ & Transit \\
\hline 7. matrix & $\mathrm{B}$ & Transit \\
\hline
\end{tabular}


following: major border crossings affect each other, while the minor ones have an effect on the closest two border crossings, and also on each other between two major ones.

The coding of the different models is the same as in the system introduced in [2].

The third methodological step of this approach is to prove the existence of spatial autocorrelation in the dataset. The presence of spatial autocorrelation depends on the weight matrix. The existence of spatial autocorrelation and the proper weight matrix can be tested by the Moran-I test. If the test results in a significant effect, a spatial econometric model can be applied [25].

$$
I=\frac{N}{S_{0}} \frac{\sum_{i, j}\left(w_{i j}\left(x_{i}-\mu\right)\left(x_{j}-\mu\right)\right)}{\sum_{i}\left(x_{i}-\mu\right)^{2}}
$$

where:

$N$ - number of investigated points

$x_{i}, x_{j}$ - the observed value of two points of interest

$\mu \quad$ - the expected value of $x$

$w_{i j}$ - the elements of the spatial weight matrix

$S_{0} \quad$ - normalizer, $S_{0}=\sum_{i, j} w_{i j}$.

If the existence of spatial autocorrelation is proven, two types of models can be set up: the spatial lag (SAR - spatial autoregressive) model and the spatial error model (SEM). In order to decide which model should be used, the Lagrange multiplier test is available $[26,28]$. If it can be assumed that the spatial lagged dependent variable also affects the dependent variable, the SAR model should be chosen. In this case, the following regression formula can be applied [25]:

$\boldsymbol{y}_{(N \times 1)}=\rho \boldsymbol{W}_{(N \times N)} \boldsymbol{y}_{(N \times 1)}+\boldsymbol{X}_{(N \times K)} \boldsymbol{\beta}_{(K \times 1)}+\boldsymbol{\varepsilon}_{(N \times 1)}$

where:

$\boldsymbol{y}$ - vector of the dependent variables

$\rho$ - autoregressive parameter

$\boldsymbol{W}$ - weight matrix

$\boldsymbol{\beta}$ - coefficient vector

$\boldsymbol{X}$ - matrix of the independent variables

$\boldsymbol{\varepsilon}$ - vector of errors $\left(E\left(\varepsilon_{i}\right)=0, V\left(\varepsilon_{i}\right)=\sigma^{2}\right)$

$N$ - number of points of interest

$K$ - number of independent variables.

If spatial dependence can be eliminated from the model, and the spatial effects can be transferred to the error term, the SEM model should be used. In this case, the formulas presented below can be used [25]:

$\boldsymbol{y}_{(N \times 1)}=\boldsymbol{X}_{(N \times K)} \boldsymbol{\beta}_{(K \times 1)}+\boldsymbol{\varepsilon}_{(N \times 1)}$
$\boldsymbol{\varepsilon}_{(N \times 1)}=\lambda \boldsymbol{W}_{(N \times N)} \boldsymbol{\varepsilon}_{(N \times 1)}+\boldsymbol{\zeta}_{(N \times 1)}$

where:

$\zeta$ - vector of spatial independent errors

$\lambda$ - autoregressive error parameter

The analysis is based upon the introduced method. The calculation was carried out by the $R$ project v.3.4.0. software and its spdep library $[25,26$, 28-32].

\section{MODEL DEVELOPMENT}

In our model the border crossings of Hungary are analyzed by the spatial econometric method for the year 2015. For this, the dependent variable is the traffic flow at each border crossing point given in vehicle unit/day/two directions. In the analyzed period (2015), there were 103 border crossings in Hungary (see Figure 1).

In the case of passenger transportation, two cases are distinguished. Trips related to shopping, commuting or fuelling are classified in the group of regular flows: while trips mostly related to leisure-time are classified in the group of irregular flows. Considering trips related to commuting, 2.1 percent of the population work abroad, and have a residence in Hungary at the same time. Most commuters live in the Györ-Moson-Sopron County, which can be explained by the closeness of Bratislava (Pozsony), Slovakia and Wien (Bécs), Austria.

The dependent variable is the amount of passenger cars crossing the border. The most important independent variables can be divided into three different groups. The first group consists of the existing international public transport network, the second group contains the agglomeration effects, while the third one describes the effect of the neighboring countries. The independent variables from our previous studies are as follows: the volume of substitution traffic modes (annual average daily traffic AADT), the population of different statistical units (number of inhabitants), the classification of road types, or the opening hours (see 0 ) $[1,2,33]$.

The collected data is mostly taken from official government databases. The AADT (annual average daily traffic) data is (the dependent variable and independent variables No. 1-2) based upon [34], which is the available data for the Hungarian national roads. In the case of non-national roads (the owner is the local city council), the data were taken from the Slovakian database [35], where available, or provided by the local mayors. As for public transport data (No. 3-8), 


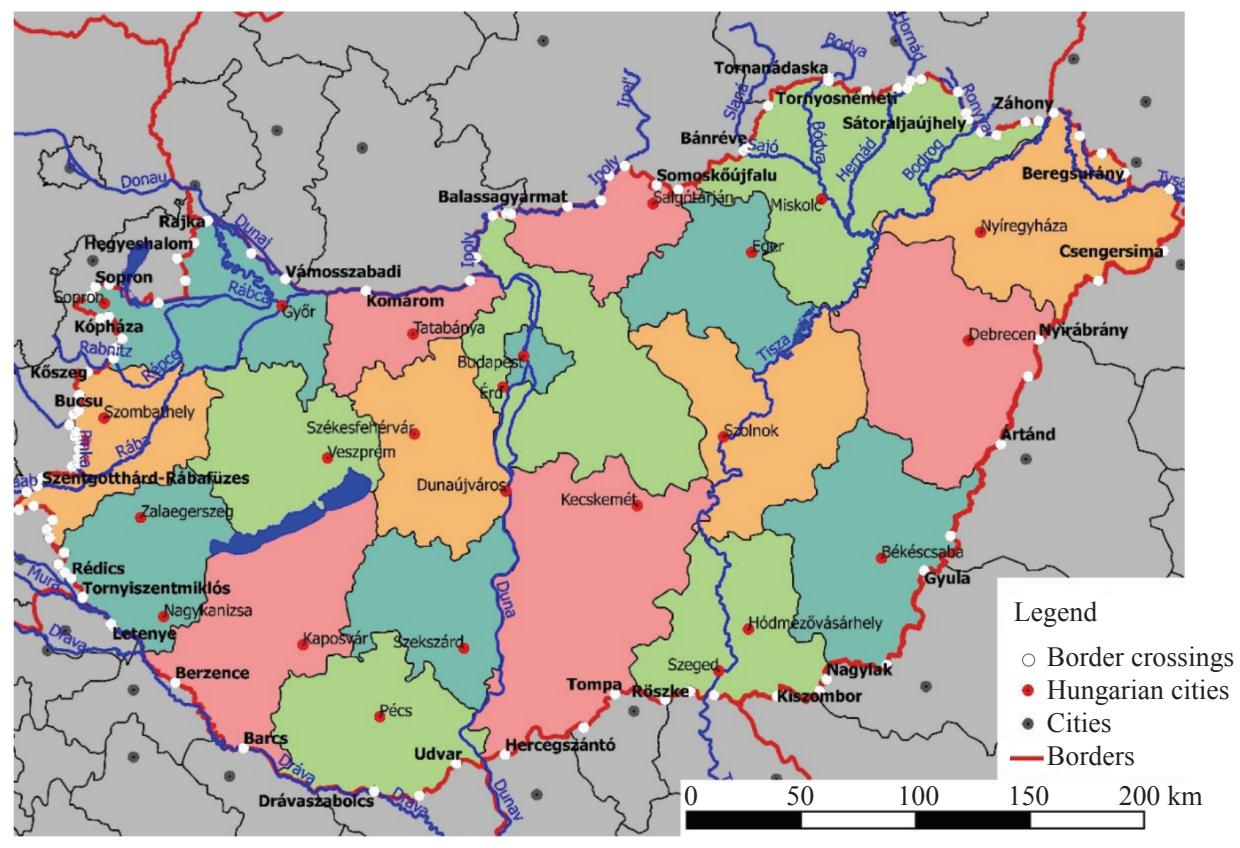

Figure 1 - The map of border crossings in Hungary

the timetables were used to calculate the proper numbers. The GDP and population data (No. 9-15 and No. 32) is based upon the Eurostat database except in case of Ukraine, where the World Bank database was used. The population data for Hungary (No. 11-13) were taken from the Hungarian Gazetteer [36], while the opening hours (No. 19) are available on the website of the Hungarian Police.

Many researchers have proven that the effect of different modes of public transportation should be taken into consideration [37-41]. In the case of public transportation networks, it is important to distinguish between international and local networks. The components of the international network provide relationships among the related neighboring countries (e.g. EuroCity service), while the local network connects the related cities.

To define the number of international lines, the first step was to get access to the timetables of cross-border lines. In most cases there were no problems in the calculation of the traffic volume. However, a lot of international bus services are only available in summer, so it is a question to what extent they can be considered in the total amount. As a result, weekly average volumes were taken into consideration since a lot of lines are only available once or twice a week.

The effect of the parallel public transport (PT) lines, which could be handled as a property of the borderland's microregion, can be complementary or competitive. If the sign of the parameter belonging to a given PT network is positive, it means that the mode cannot be an alternative for using the car. However, if the sign is negative that means that with the increasing number of departures, the number of passenger cars will be lower, so we can speak about a competitive role.

The variables of the second group are based on the distance of the cities from the border. Borders in the $20^{\text {th }}$ century were significantly changed in Central-Europe, while the relationship and the connection structure of the settlements have only been able to adapt slowly to the new situation. These traditional structures have been influenced by border changes; therefore, it can be assumed that some cross-border demand may originate from the agglomeration effect. This type of travel demand can be connected to cities with approximately more than 15,000 inhabitants. The agglomeration effect can be described by the population of the central city, while the distance from the border is described by a distance decay function [42]. These parameters can be defined for cities inside and outside Hungary as well.

The results of the general model $[1,33]$ suggest that this kind of approach cannot provide an efficient estimation model. In accordance with the previously presented outputs, a new approach has been introduced. The new variable (No. 17-18) is based on the population of the related Hungarian and neighboring agglomeration city, and the reciprocal 
Sipos T, Szabó Z, Török Á. Spatial Econometric Cross-Border Traffic Analysis for Passenger Cars - Hungarian Experience

Table 2 - The variables used and their descriptio

\begin{tabular}{|c|c|c|}
\hline $\begin{array}{l}\text { Var. } \\
\text { No. }\end{array}$ & Variable name & Variable Description \\
\hline 1 & Bus & AADT of buses \\
\hline 2 & Bicycle & AADT of bicycles \\
\hline 3 & National bus & Weekly average number of international buses \\
\hline 4 & Regional bus & Weekly average number of regional buses \\
\hline 5 & Summed bus & Summed weekly average number of buses \\
\hline 6 & National train & Weekly average number of international trains \\
\hline 7 & Regional train & Weekly average number of regional trains \\
\hline 8 & Summed train & Summed weekly average number of trains \\
\hline 9 & Hu GDP 2015 & Hungarian GDP of the given NUTS2 region in 2015 \\
\hline 10 & Abroad GDP 2015 & GDP of the neighbor NUTS2 region in 2015 \\
\hline 11 & Hu county & Population of the Hungarian county where the border crossing is \\
\hline 12 & Hu districts & Population of the Hungarian district where the border crossing is \\
\hline 13 & Hu settlement & Population of the Hungarian settlement where the border crossing is \\
\hline 14 & Abroad NUTS3 & Population of the neighboring country's NUTS3 region where the border crossing is \\
\hline 15 & Abroad settlement & Population of the neighboring country's settlement where the border crossing is \\
\hline 16 & Hu Agglomeration & Agglomeration effect of the Hungarian side \\
\hline 17 & Abroad Agglo. & Agglomeration effect of the neighboring country's side \\
\hline 18 & Summed Agglo. & Summary of the agglomeration effects \\
\hline 19 & Opening hours & Amount of weekly opening hours of the border crossing point \\
\hline 20 & Austria & \multirow{6}{*}{ Dummy variable for the neighboring country } \\
\hline 21 & Croatia & \\
\hline 22 & Romania & \\
\hline 23 & Serbia & \\
\hline 24 & Slovakia & \\
\hline 25 & Slovenia & \\
\hline 26 & Hu Spatial Ineq. & \multirow{2}{*}{$\begin{array}{l}\text { Country specified spatial inequality parameters weighted by the distance from the } \\
\text { capital }\end{array}$} \\
\hline 27 & Abroad Spatial Ineq. & \\
\hline 28 & Motorways & \multirow{3}{*}{$\begin{array}{l}\text { Dummy variable for the connection types between the different types of road (based on } \\
{[34] \text { ) }}\end{array}$} \\
\hline 29 & Motorway road & \\
\hline 30 & Main roads & \\
\hline 31 & River width & Width of the river (if there is one) - based on personal measurement \\
\hline 32 & GDP & GDP of the neighboring country in 2015 \\
\hline 33 & Schengen & Dummy variable for the membership of the Schengen countries \\
\hline 34 & EU & Dummy variable for the membership of the European Union \\
\hline 35 & Fuel price & Ratio between the yearly average fuel prices in 2015 \\
\hline
\end{tabular}

of the square of the distances [43]. The formula of the newly introduced variable can be presented as follows:

Summed Agglo. $=\frac{m_{H U}}{r_{H U}^{2}}+\frac{m_{A B}}{r_{A B}^{2}}$

where:

$m_{H U}$ - the population of the Hungarian city [number of inhabitants]

$m_{A B} \quad$ - the population of the neighboring country's city [number of inhabitants]
$r_{H U}=$ the distance of the Hungarian city from the investigated border section $[\mathrm{km}]$

$r_{A B}$ - the distance of the neighboring city from the investigated border section $[\mathrm{km}]$.

In order to introduce the third variable group, the consideration of Limão and Venables [44] was used, which assumes that the simplest way to represent the country effect on border crossing traffic is the introduction of dummy variables. In our case, six dummy variables had to be introduced in 
accordance with the number of neighboring countries. Ukraine was selected to be the reference value for the dummy variables.

Furthermore, Maoh, Khan and Anderson [7] applied a different set of variables to model the above mentioned effects. In the present article, the two approaches are compared. Even though GDP is frequently used to describe economic competitiveness [45], in our model GDP per capita is used because it expresses the expected standard of living in a more articulated way. Our approach differs from the previously implemented studies in other respects as well, since the methodology has to be suited to the specific characteristics of Hungary. The main differences are the following. Instead of the dummy variables describing the resistance-like characteristic of borders, the effect of the EU and the Schengen agreement should be analyzed, because European researchers [13-15] suggested that for Europe, the effect of integration is more important. Based on the results of the preparatory evaluation, the variables related to Schengen Agreement membership and to the introduction of Euro are correlated in case of the neighboring countries, so only one of them is proposed to be used.

Finally, a new set of decision variables should be introduced (No. 26-27). These dependent variables had a significant role in [2]. The role of these variables is to take into consideration spatial inequalities. The idea of introducing these variables is from Auerbach [43, 46], where he concludes that in the optimal case the population of the $n^{\text {th }}$ largest city (or primate city [43]) equals to the $1 / n$ fraction of the population of the largest city. Therefore, in an ideal case, the number of inhabitants in the second largest city is the half of the primate city population. Based upon this rule, a variable can be calculated, which is the fraction of the population of the two largest cities, with a result being higher than one. For example, in Hungary the largest city is Budapest (population: $1,749,734$ ) [36], while the second largest one is Debrecen (population: 202,214), so the Spatial Inequality Index is 8.65 , which is the highest one in Europe not taking into consideration the Caucasian countries. The decision variable is calculated from this number weighted by the distance from the largest city.

In order to determine the most important effects, three cases need to be analyzed:
- the effects of the neighboring countries: modelled by dummy variables $(0)$, or absolute values of the selected economic factors (1) [7],

- the agglomeration effects of the Hungarian and foreign cities related to a border section are summarized (1) or not (0),

- the parallel bus and rail services are divided into national and regional subgroups (0) or not (1).

Based on the combination of the three cases, eight models can be set up. To differentiate the eight models from each other, a coding system was introduced, as it can be seen in the list above. According to the basic idea behind the coding system, there are three different cases and two different groups of independent variables.

In accordance with this, each model's code contains three binary digits. Each digit refers to one of the cases (for example, the model 000 is modelled by dummies, the agglomeration effects are not contracted, and the parallel bus and rail services are divided into regional and national subgroups).

\section{RESULTS}

\subsection{Results of the OLS models}

The eight models are presented in the following two tables. The results of the first four models (in which the dummy variables are used) can be seen in Table 3. The significance level is indicated in the tables by the following notations: . stands for $p<0.1$, $*$ stands for $p<0.05, * *$ stands for $p<0.01$, and $* * *$ stands for $p<0.001$ [30-32].

As it can be seen from Table 3, the overall effect of the different parameters on the models is significant, with a quite high $R^{2}$ value (bottom row, Table 3). On the one hand, if the parallel bus and rail traffic flows are taken into consideration separately, the coefficient of the buses becomes positive, while the coefficient of the bicycles remains negative. On the other hand, the effect of bicycle traffic is never significant, and the effect of bus traffic is significant only in the cases when the parallel bus and rail services are not differentiated to national and regional ones. If the parallel services are analyzed, further counterproductive processes can be observed. The reason for this is the competition between services which appears stronger and stronger if the analysis of the cooperation among services is moved from a national level to a regional level. In the case of buses, the national lines have a rather complementary role in cross-border commuting, while the regional 


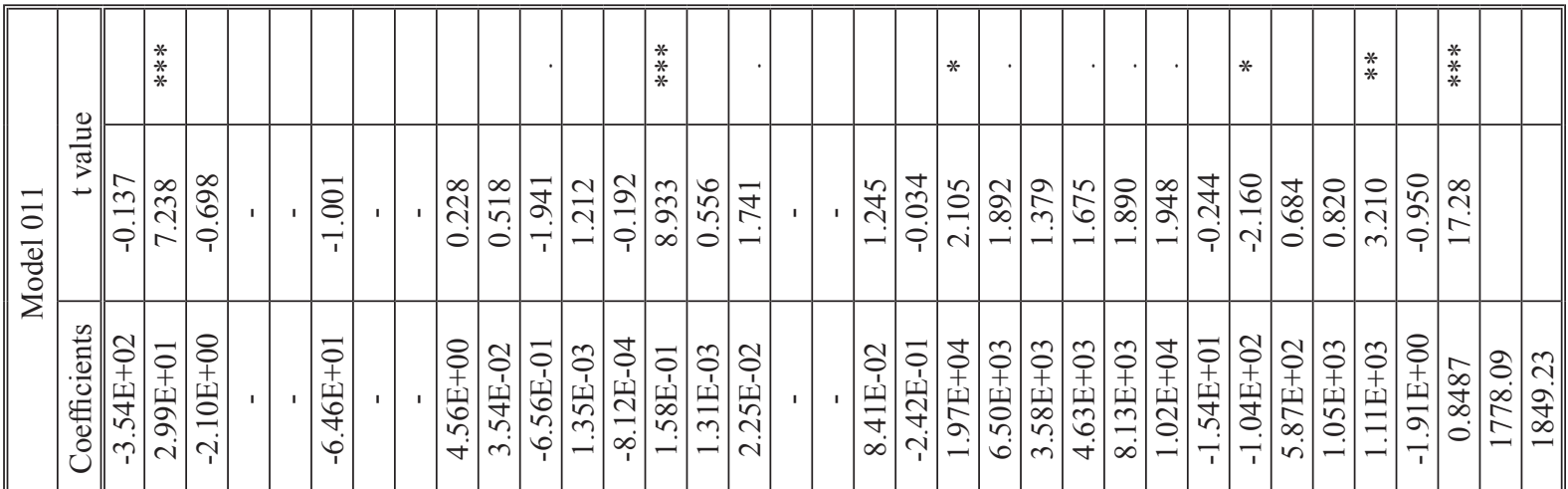

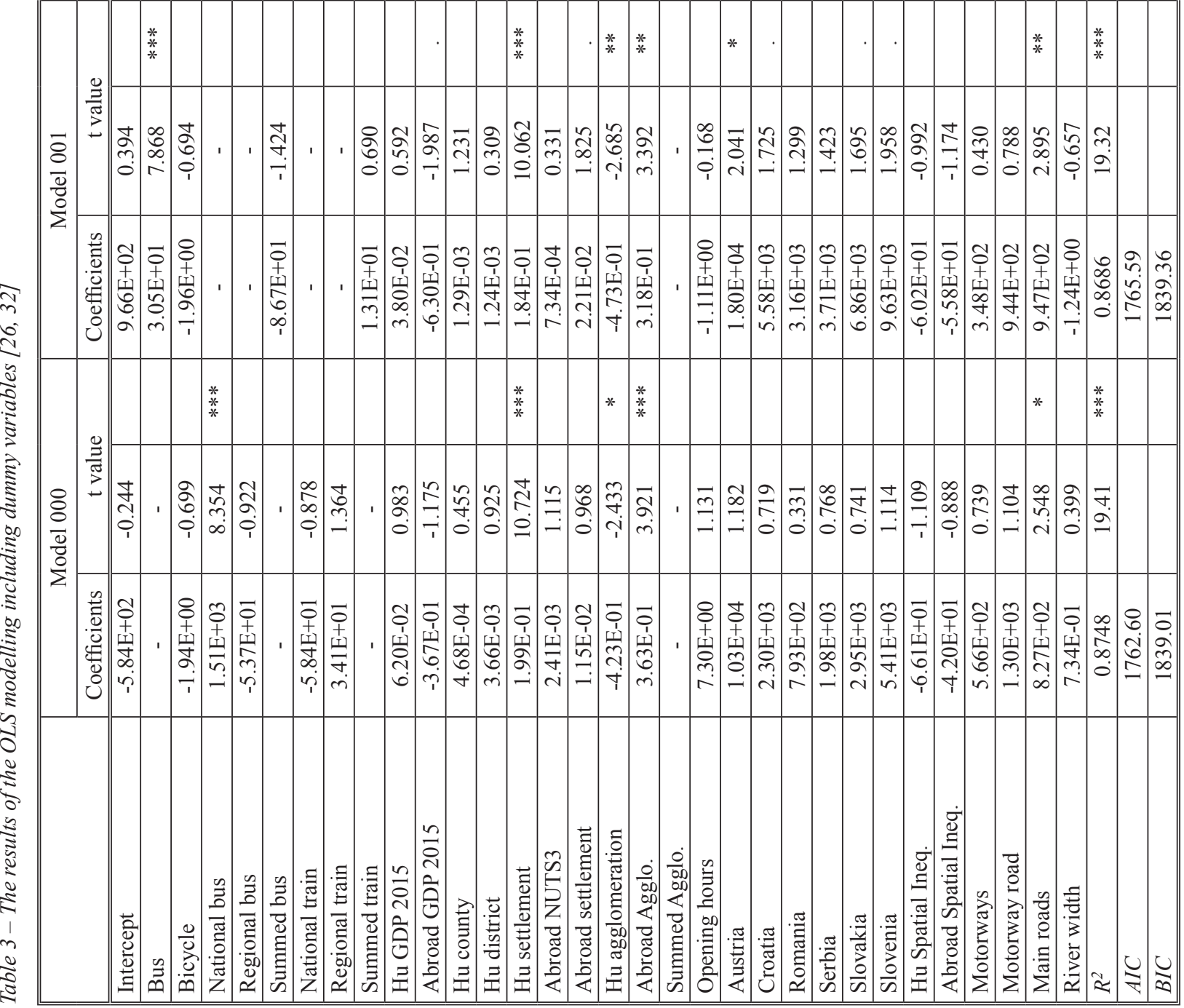


ones seem to have a competitor role (the effects are significant in the case of national ones). The effect of railway lines is just the opposite of that of buses, so the regional lines have a complementary role, while the national lines rather have a competitive effect (which are not significant). When merged effects are considered, bus services seem to have competitive effects; however, neither the bus services nor the rail services have significant effects.

Concerning the built-up area effect (influence of the settlements based on their population and distance from the analyzed border section), only the effects of the closest settlements are significant. At the same time, borderlands do not affect the estimation significantly, neither on the Hungarian side, nor in the case of the neighboring country. In the case of the closest settlements, the effect of the Hungarian closest settlement is always strongly significant, while the effect of the neighboring country settlements is only significant if the parallel bus and rail services are considered together. Investigating the agglomeration effects, it can be seen that the neighboring countries' larger cities have an appreciably high absorption effect, supplied by the Hungarian side, while this is not true in the opposite direction. The reason is probably the suburbanization of these cities. People who are relocating their living places are going to commute across the border.

If the dummy variables of the neighboring countries are taken into consideration, it can be seen that Austria exercises the strongest effect, followed by Slovenia, Slovakia, Croatia, Serbia, and Romania, respectively. All the coefficients are positive, meaning that the last one is Ukraine, which was the basis of the dummy variables. However, the values are not always significant.

If the effects of the neighboring countries are modelled by absolute values (Table 4), the previously shown effects do not change significantly. However, the country-based dependent dummy variables need to be analyzed further. Since the dummy-based evaluation of the neighboring countries' effect has resulted in well differentiable ordered classes of the countries, this approach cannot be substituted by an absolute variable based analysis. Neither the effect of the EU, nor the effect of the Schengen Agreement seem to be significant; besides, the coefficient of the Schengen Agreement is negative in some cases. The other county dependent variables do not seem to have any effect on the model either.

\subsection{Results of the spatial econometric models}

In order to do the spatial econometric analysis, spatial econometric models should be set up on the existing OLS models. Eight types of weight matrices are used to find proper models with existing spatial autocorrelation.

In order to eliminate the spatial effect, spatial econometric models can be used. Based on the results of our analysis, significant spatial autocorrelation can be shown in five cases, thus five models can be set up. These can be seen in Table 5. In three cases, the SEM models can be applied (Model 0107, Model 0117, and Model 1107), while in two cases the SAR models seem to give the appropriate solution. Only the first two models' $p$-value is below 10 percent, the other ones are slightly above this threshold. Furthermore, the SAR models do not work properly for this problem, since they could not demonstrate significant spatial effects. Thus in the further analysis the SEM models are to be applied.

The application of the SEM approach does not significantly change the results, which assumes parallel flows. The only exceptions are the effects of international railway lines, which become significant when the direction of the coefficients are changed (in these cases the coefficient of regional lines are negative as well as in case of the bus lines).

The effects related to the borderlands' population have not changed significantly either; however, a few of them become significant. For example, in Model 1107 the parameter of the closest neighboring settlement became negative. This model differs from Model 0107 in the representation of the country effect; hence, it seems to be rational that the change of sign of the closest neighboring settlement's parameter can be explained by this modification. It is conceivable that the reason behind the change in the sign of the closest neighboring settlements' coefficient is the partial appearance of the country effect in the discussed variable.

If spatial inequality parameters are taken into consideration, the effects of the neighboring countries seem to be significant; however, the sign of the parameters are predicted to be positive. The reason for this has not been clarified yet, further research is required.

The order of the countries in the case of dummy variables remains the same as in the OLS models. In the spatial models some of them have also become significant. However, the application of 


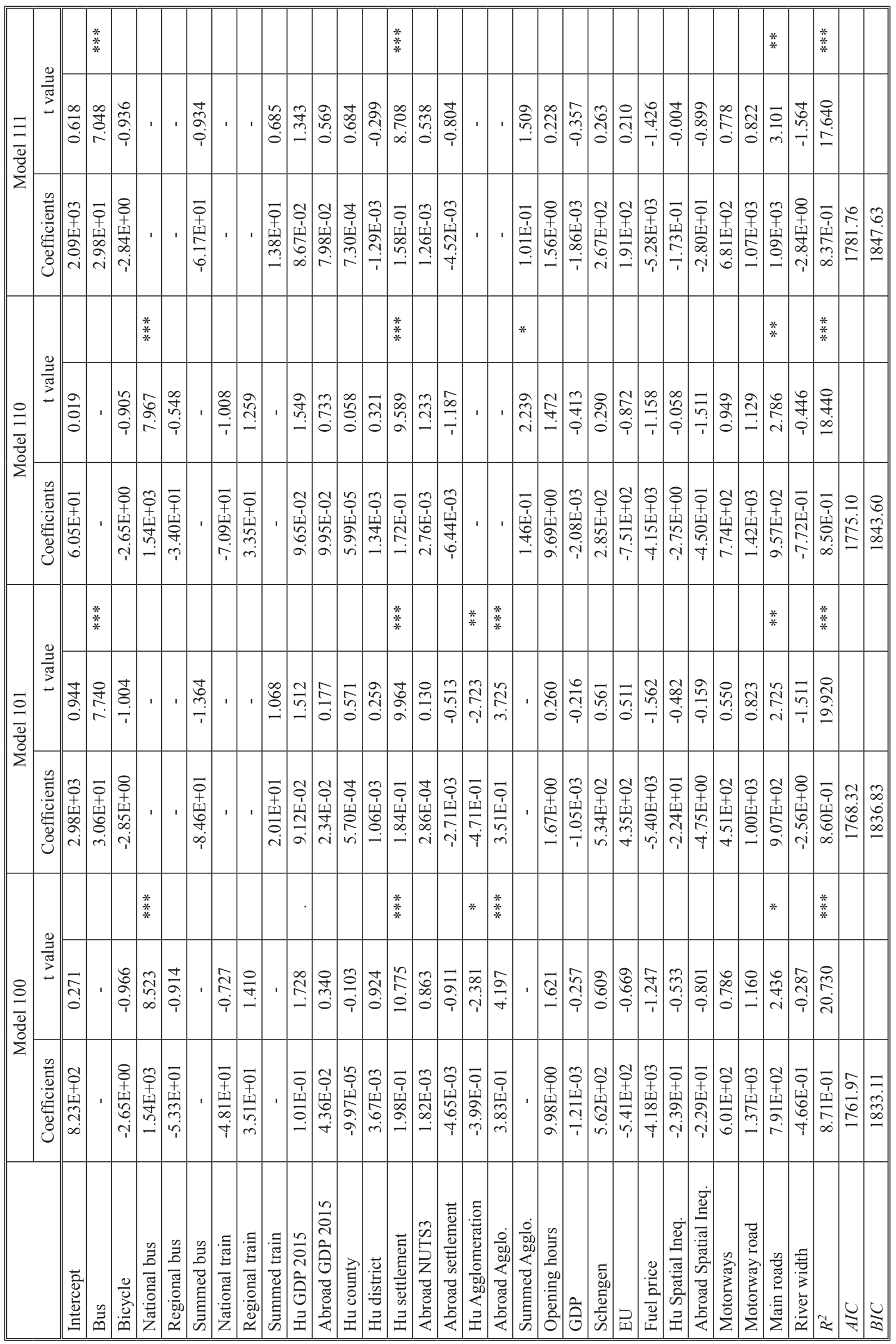


Sipos T, Szabó Z, Török Á. Spatial Econometric Cross-Border Traffic Analysis for Passenger Cars - Hungarian Experience

Table 5 - The properties of the best models [26, 29-32]

\begin{tabular}{||l|c|c|c|c|c||}
\hline & Model 0107 & Model 0117 & Model 1015 & Model 1107 & Model 1115 \\
\hline \hline Type of matrix & $\mathrm{B}$ & $\mathrm{B}$ & $\mathrm{B}$ & $\mathrm{B}$ & $\mathrm{B}$ \\
\hline Assignment & Transit & Transit & Main road & Transit & Main road \\
\hline Moran I & -0.0742 & -0.0785 & -0.0182 & -0.0715 & -0.021 \\
\hline Moran I's p-value & 0.0988 & 0.0645 & 0.1139 & 0.1046 & 0.1275 \\
\hline LMerr p-value & 0.0467 & 0.03536 & 0.7582 & 0.0554 & 0.723 \\
\hline LMlag p-value & 0.397 & 0.2035 & 0.2647 & 0.4468 & 0.2698 \\
\hline RLMerr p-value & 0.0653 & 0.06353 & 0.2036 & 0.0738 & 0.1616 \\
\hline RLMlag p-value & 0.6911 & 0.4265 & 0.09631 & 0.7442 & 0.0807 \\
\hline
\end{tabular}

Table 6-Results of the proper SEM models [26, 29-32]

\begin{tabular}{|c|c|c|c|c|c|c|c|c|c|}
\hline \multirow[b]{3}{*}{ Intercept } & \multicolumn{3}{|c|}{ Model 0107} & \multicolumn{3}{|c|}{ Model 0117} & \multicolumn{3}{|c|}{ Model 1107} \\
\hline & \multirow{2}{*}{$\begin{array}{c}\text { Coefficients } \\
-2.22 \mathrm{E}+03\end{array}$} & \multicolumn{2}{|c|}{$\mathrm{z}$ value } & \multirow{2}{*}{$\begin{array}{c}\text { Coefficients } \\
-2.06 \mathrm{E}+02\end{array}$} & \multicolumn{2}{|c|}{$\mathrm{z}$ value } & \multirow{2}{*}{$\begin{array}{c}\text { Coefficients } \\
-7.08 \mathrm{E}+02\end{array}$} & \multicolumn{2}{|c|}{$\mathrm{z}$ value } \\
\hline & & -1.337 & & & -0.113 & & & -0.368 & \\
\hline Bus & - & - & & $3.07 \mathrm{E}+01$ & 8.233 & $* * *$ & - & - & \\
\hline Bicycle & $2.18 \mathrm{E}+00$ & 1.035 & & $8.54 \mathrm{E}-01$ & 0.380 & & 8.64E-01 & 0.401 & \\
\hline National bus & $1.55 \mathrm{E}+03$ & 9.073 & $* *$ & - & - & & $1.65 \mathrm{E}+03$ & 9.586 & $* * *$ \\
\hline Regional bus & $-6.43 \mathrm{E}+01$ & -1.152 & & - & - & & $-5.83 \mathrm{E}+01$ & -1.012 & \\
\hline Summed bus & - & - & & $-8.71 \mathrm{E}+01$ & -1.499 & & - & - & \\
\hline National train & $3.55 \mathrm{E}+01$ & 0.582 & & - & - & & $3.86 \mathrm{E}+01$ & 0.613 & \\
\hline Regional train & $-4.08 \mathrm{E}+01$ & -1.707 & . & - & - & & $-3.91 \mathrm{E}+01$ & -1.596 & \\
\hline Summed train & - & - & & $-1.89 \mathrm{E}+01$ & -1.373 & & - & - & \\
\hline Hu GDP 2015 & 8.98E-02 & 2.132 & $*$ & $8.85 \mathrm{E}-02$ & 1.971 & $*$ & $1.48 \mathrm{E}-01$ & 3.818 & $* * *$ \\
\hline Abroad GDP 2015 & $-3.32 \mathrm{E}-01$ & -1.822 & . & $-6.39 \mathrm{E}-01$ & -3.223 & $* *$ & $1.37 \mathrm{E}-01$ & 1.685 & . \\
\hline Hu county & $6.23 \mathrm{E}-04$ & 0.818 & & $8.50 \mathrm{E}-04$ & 1.044 & & $-2.13 \mathrm{E}-04$ & -0.289 & \\
\hline Hu district & 4.99E-03 & 1.697 & . & $2.38 \mathrm{E}-04$ & 0.079 & & 4.93E-03 & 1.637 & \\
\hline Hu settlement & $1.73 \mathrm{E}-01$ & 12.122 & $* * *$ & $1.55 \mathrm{E}-01$ & 10.520 & $* * *$ & $1.72 \mathrm{E}-01$ & 11.539 & $* * *$ \\
\hline Abroad NUTS3 & 4.45E-03 & 3.055 & $* *$ & 2.62E-03 & 1.602 & & 3.99E-03 & 2.681 & $* *$ \\
\hline Abroad settlement & $1.05 \mathrm{E}-02$ & 1.411 & & $2.26 \mathrm{E}-02$ & 2.794 & $* *$ & $-8.99 \mathrm{E}-03$ & -2.734 & $* *$ \\
\hline Summed Agglo. & $8.51 \mathrm{E}-02$ & 1.443 & & 4.31E-02 & 0.720 & & 9.44E-02 & 1.671 & . \\
\hline Opening hours & $6.60 \mathrm{E}+00$ & 1.109 & & $3.88 \mathrm{E}-01$ & 0.063 & & $1.06 \mathrm{E}+01$ & 1.788 & . \\
\hline Austria & $1.01 \mathrm{E}+04$ & 2.001 & $*$ & $1.83 \mathrm{E}+04$ & 3.350 & $* * *$ & - & - & \\
\hline Croatia & $2.63 \mathrm{E}+03$ & 1.457 & & $5.89 \mathrm{E}+03$ & 2.985 & $* *$ & - & - & \\
\hline Romania & $5.49 \mathrm{E}+02$ & 0.400 & & $2.87 \mathrm{E}+03$ & 1.902 & . & - & - & \\
\hline Serbia & $2.30 \mathrm{E}+03$ & 1.597 & & $4.00 \mathrm{E}+03$ & 2.548 & $*$ & - & - & \\
\hline Slovakia & $2.31 \mathrm{E}+03$ & 1.066 & & $6.31 \mathrm{E}+03$ & 2.629 & $* *$ & - & - & \\
\hline Slovenia & $5.62 \mathrm{E}+03$ & 1.910 & . & $9.65 \mathrm{E}+03$ & 3.031 & $* *$ & - & - & \\
\hline GDP & - & - & & - & - & & $-4.50 \mathrm{E}-03$ & -1.462 & \\
\hline Schengen & - & - & & - & - & & $-1.29 \mathrm{E}+02$ & -0.203 & \\
\hline $\mathrm{EU}$ & - & - & & - & - & & $-6.74 \mathrm{E}+02$ & -1.137 & \\
\hline Fuel Price & - & - & & - & - & & $-5.01 \mathrm{E}+03$ & -2.398 & $*$ \\
\hline Hu Spatial Ineq. & $-4.89 \mathrm{E}+01$ & -1.228 & & $-5.51 \mathrm{E}+01$ & -1.278 & & $1.18 \mathrm{E}+01$ & 0.421 & \\
\hline Abroad Spatial Ineq. & $-6.62 \mathrm{E}+01$ & -2.945 & $* *$ & $-7.67 \mathrm{E}+01$ & -3.036 & $* *$ & $-5.36 \mathrm{E}+01$ & -3.350 & $* * *$ \\
\hline Motorways & $7.98 \mathrm{E}+02$ & 1.195 & & $6.37 \mathrm{E}+02$ & 0.869 & & $8.61 \mathrm{E}+02$ & 1.240 & \\
\hline Motorway road & $1.17 \mathrm{E}+03$ & 0.885 & & $9.95 \mathrm{E}+02$ & 0.757 & & $1.57 \mathrm{E}+03$ & 1.175 & \\
\hline Main roads & $1.19 \mathrm{E}+03$ & 4.784 & $* * *$ & $1.13 \mathrm{E}+03$ & 4.477 & $* * *$ & $1.14 \mathrm{E}+03$ & 4.640 & $* * *$ \\
\hline River width & $-3.54 \mathrm{E}-02$ & -0.023 & & $-2.46 \mathrm{E}+00$ & -1.484 & & $-1.98 \mathrm{E}+00$ & -1.402 & \\
\hline$\lambda$ & -0.21686 & -8.51 & $* * *$ & -0.17814 & -5.81 & $* * *$ & -0.20293 & -7.33 & $* * *$ \\
\hline
\end{tabular}


absolute values for the selected economic factors has not proven to be efficient regarding the evaluation of the countries' effect on border crossing traffic.

The data for comparing the different models is given in Table 7. This contains the calculated Akaike-, Bayes- and Consistent Akaike Information Criteria (AIC, BIC, CAIC). Spatial autocorrelation is present in the OLS models (Model 010, Model 011, Model 110), so we can state that there is a chance of a false strong connection [47]. In addition to the $\mathrm{AIC}, \mathrm{BIC}, \mathrm{CAIC}$, and $\mathrm{R}$, the pseudo- $R^{2}$ value was calculated to evaluate the SEM models [24]. All of these parameters can be taken into consideration to compare the goodness-of-fit. In case of Model 0107 and Model 1107, the $R^{2}$ value is lower compared to the standard OLS versions, in the respective Model 010 and Model 110, thus the false strong connection is confirmed. Even though Model 0117 has the highest AIC values, it can be seen that the z-value is the lowest one. The most important fact is that the pseudo- $R^{2}$ value is much higher than in the other models. This indicates that the Model 0117 results can be applied for further investigations.

Based on the Model 0117, as an example, it is worth analyzing the border crossing on Road 6 between Barcs and Terezino Polje (Trézenföld), Croatia. In Hungary this is the end of Road 6, which is a first class national road connecting Budapest and Pécs ( $5^{\text {th }}$ largest city in Hungary). According the model, significantly larger traffic is estimated (727 passenger vehicles instead of 379). The lack of traffic can be explained by the fact that there is a demand for cross-border traffic, but a lot of people cannot afford it. In order to avoid this, an international bus line is recommended to be introduced between Virovitica (Veröce) and Barcs or Pécs, maybe connecting to the railway line toward Pécs and Szigetvár. With this, new opportunities will be available for the residents, and it may lead to a higher standard of living in the area, with a proper tariff policy $[48,49]$.

\section{CONCLUSION}

In this article different models were set up to examine the passenger car traffic flow of Hungarian border-crossings. With the parameter estimation, the effects of the analyzed macroregion properties were clarified. Using the same methodology, a similar analysis can be carried out for other countries or regions.

In general, the results of the passenger models have shown that the regional railway and bus lines have some competitive effects, while the international ones have a rather complementary role. This means that if cross-border work is to be supported, a proper cross-border public transport service should be introduced. As for Hungary, in recent years two of the railway lines were reopened (Mosonmagyaróvár, Hungary-Bratislava (Pozsony), Slovakia and Magyarbóly, Hungary-Beli Manastir (Pélmonostor), Croatia), and there is an increasing demand for reopening other lines. The effectiveness of these connections has not been measured in the present article, but empirical evidence says that it could have a very important role.

The other important result is that the main direction of cross-border commuting is from Hungary into the neighboring countries, which can probably be explained by the cross-border commuting traffic of the foreign population who moved to Hungary

Table 7 - Comparison of the spatial econometric models [26, 29-32]

\begin{tabular}{||c|c|c|c|c|c|c||}
\hline \multirow{2}{*}{} & \multicolumn{3}{|c|}{ OLS } & \multicolumn{3}{c||}{ SEM } \\
\cline { 2 - 7 } & Model 010 & Model 011 & Model 110 & Model 0107 & Model 0117 & Model 1107 \\
\hline \hline$\lambda$ & - & - & - & -0.2169 & -0.1781 & -0.2029 \\
\hline$F / z$-value & $17.29 * * *$ & $17.28^{* * *}$ & $18.44^{* * *}$ & $-8.5142^{* * *}$ & $-5.8147^{* * *}$ & $-7.3341^{* * *}$ \\
\hline$p$-value & $2.20 \mathrm{E}-16$ & $2.20 \mathrm{E}-16$ & $2.20 \mathrm{E}-16$ & $2.22 \mathrm{E}-16$ & $6.07 \mathrm{E}-09$ & $2.23 \mathrm{E}-13$ \\
\hline$R^{2}$ & 0.8554 & 0.8487 & 0.8502 & - & - & - \\
\hline Pseudo- $R^{2}$ & - & - & - & 0.4602 & 0.9753 & 0.7838 \\
\hline$L_{c}$ & -859.7367 & -862.0439 & -861.5496 & -847.6694 & -851.7306 & -851.6274 \\
\hline AIC & 1775.473 & 1778.088 & 1775.099 & 1753.3388 & 1759.4612 & 1757.2548 \\
\hline BIC & 1849.246 & 1849.225 & 1843.602 & 1829.7459 & 1833.2336 & 1828.3925 \\
\hline$C A I C$ & 1877.246 & 1876.225 & 1869.602 & 1858.7459 & 1861.2336 & 1855.3925 \\
\hline
\end{tabular}


due to the suburbanization of the large cities close to the border. In accordance with this, developments should be assessed in those cases where a populous city is on the other side of the border (e.g. Bratislava (Pozsony), Slovakia; Ужгород (Uzhhorod - Ungvár), Ukraine; Oradea (Nagyvárad) or Arad, Romania; Суботица (Subotica - Szabadka), Serbia; Osijek (Eszék), Croatia; Vienna (Wien - Bécs), Austria.

As it stands, the research only reflects the conditions in Hungary in 2015, therefore the findings also apply to this date. In addition, only passenger car traffic was included, which in turn allowed the use of special explanatory variables. Despite all these limitations, however, this is an acceptable basic model for Hungary, which, by using these parameters, may be suitable for extending to a larger region, such as the V4 countries, Central Europe, or even the entire European Union.

SIPOS TIBOR, Ph.D. ${ }^{1}$

E-mail: sipos.tibor@mail.bme.hu

SZABÓ ZSOMBOR, Ph.D. ${ }^{1}$

E-mail: szabo.zsombor@mail.bme.hu

TÖRÖK ÁRPÁD, Ph.D. ${ }^{2}$

Email: arpad.torok@gjt.bme.hu

${ }^{1}$ Budapesti Müszaki és Gazdaságtudományi Egyetem

Közlekedésmérnöki és Jármümérnöki Kar

Közlekedésüzemi és Közlekedésgazdasági Tanszék

Mủegyetem rakpart 3, H-1111 Budapest, Magyarország

${ }^{2}$ Budapesti Müszaki és Gazdaságtudományi Egyetem

Közlekedésmérnöki és Járműmérnöki Kar

Gépjármütechnológia Tanszék

Műegyetem rakpart 3, H-1111 Budapest, Magyarország

\section{SZEMÉLYGÉPJARMÜVEK \\ HATÁRFORGALMÁNAK \\ TÉRÖKONOMETRIAI \\ ELEMZÉSE - MAGYARORSZÁGI PÉLDA}

\section{ABSZTRAKT}

A határon átnyúló ingázó jellegü közlekedési igények szerepe kiemelkedö, tekintve, hogy a határmenti nagyvárosok jellemzöen magas forgalomvonzó képességgel rendelkeznek. Tehát az agglomerációs hatások erösen érvényesülnek a határmenti településeken. Ezt tetézi, hogy mind Magyarországot mind pedig a környezö országokat területi egyenlötlenség terheli, ezért az egyes határátkelök forgalma nem kiegyenlitett. Célunk kimutatni, hogy az egyes közforgalmú közlekedési módok bevezetése, milyen mértékben hat a határokon kialakult személygépjármüforgalom csökkenésére. Ennek érdekében olyan térökönometriai modellt állítottunk fel, amely egyszerre képes kezelni a párhuzamos közösségi közlekedési infrastruktúrát, a határmenti nagyvárosok határon átnyúló forgalomvonzó képességét és a területi egyenlötlenségek forgalombefolyásoló hatását. A kutatás eredménye hozzájárul ahhoz, hogy az egyes közlekedési eszközök bevezetése milyen mértékben segíti elö a határmenti régiók versenyképességének növekedését. Mindezzel olyan politikai eszközök hatásosságát lehet bizonyítani, amellyel az adott makrorégió versenyképessége javitható.

\section{KULCSSZAVAK}

közlekedésföldrajz; térökonometria; térbeli elválasztás; határforgalom.

\section{REFERENCES}

[1] Szabó Z, Sipos T, Török Á. Spatial Econometric Analysis of the Hungarian Border Crossings. MATEC Web of Conferences. 2017;134: 00057. DOI: 10.1051/matecconf/201713400057 [Accessed 11th July 2018].

[2] Szabó Z, Török Á. Tranzitforgalmak Magyarországon: Egy térökonometriai elemzés. In: Horváth $\mathrm{B}$, Horváth G, Gaál B. (eds.) Proceedings of the $8^{\text {th }}$ Conference on Transport Sciences, 22 - 23 March 2018, Györ, Hungary. 2018. p. 201-212. Hungarian.

[3] Maghrour Zefreh M, Török Á, Mészáros F. Average Vehicles Length in Two-lane Urban Roads: A Case Study in Budapest. Periodica Polytechnica Transportation Engineering. 2017;45(4): 218-222. DOI: 10.3311/PPtr.10744 [Accessed 22nd Feb 2019].

[4] Meyer MD, Miller EJ. Urban Transportation Planning. $2^{\text {nd }}$ ed. New York, NY: McGraw-Hill; 2000.

[5] Opasanon S, Kitthamkesorn S. Border crossing design in light of the ASEAN Economic Community: Simulation based approach. Transport Policy. 2016;48: 1-12. DOI: 10.1016/j.tranpol.2016.02.009 [Accessed 11 th July 2018].

[6] Bradbury SL. The impact of security on travelers across the Canada-US border. Journal of Transport Geography. 2013;26: 139-46. DOI: 10.1016/j.jtrangeo.2012.08.009 [Accessed 11th July 2018].

[7] Maoh HF, Khan SA, Anderson WP. Truck movement across the Canada-US border: The effects of $9 / 11$ and other factors. Journal of Transport Geography. 2016;53: 12-21. DOI: 10.1016/j.jtrangeo.2016.04.002 [Accessed 11th July 2018].

[8] Burt M. Tighter Border Security and Its Effect on Canadian Exports. Canadian Public Policy / Analyse de Politiques. 2009;35(2): 149-169.

[9] Anderson WP, Maoh HF, Burke CM. Passenger car flows across the Canada-US border: The effect of 9/11. Transport Policy. 2014;35: 50-56. DOI: 10.1016/ j.tranpol.2014.05.005 [Accessed 27th Nov 2018].

[10] Burke CM. A comparative analysis of cross border travel influences at the port level: Pacific Highway/Douglas, B.C. - Blaine, WA and Windsor, ON - Detroit, MI. Research in Transportation Business \& Management. 2015;16: 95-101. DOI: 10.1016/j.rtbm.2015.07.001 [Accessed 11th July 2018].

[11] A. Abd M, Al Rubeaai SF, Salimpour S, Azab A. Evolutionary game theoretical approach for equilibrium of cross-border traffic. Transportmetrica $B$ : 
Transport Dynamics. 2019;7(1): 1611-1626. DOI: 10.1080/21680566.2019.1670116 [Accessed 18th Jul 2020].

[12] Sener IN, Lorenzini KM, Aldrete RM. A synthesis on cross-border travel: Focus on El Paso, Texas, retail sales, and pedestrian travel. Research in Transportation Business \& Management. 2015;16: 102-111. DOI: 10.1016/ j.rtbm.2015.05.002 [Accessed 11th July 2018].

[13] Niebuhr A. The Impact of EU Enlargement on European Border Regions. Hamburg Institute of International Economics. HWWA Discussion Paper No. 330, 2005.

[14] Tagai G, Pénzes J, Molnár E. Methods of the analysis of integration effect on border areas - The case of Hungary. Eurolimes - Journal of the Institute for Euroregional Studies. 2008;6: 150-160.

[15] Condeço-Melhorado A, Christidis P. Road Accessibility in Border Regions: A Joint Approach. Networks and Spatial Economics 2018;18(2): 363-383. DOI: 10.1007/ s11067-017-9362-1 [Accessed 25th Mar 2019].

[16] Moran PAP. Some Theorems on Time Series: II The Significance of the Serial Correlation Coefficient. Biometrika. 1948;35(3/4): 255-260. DOI: 10.2307/2332344 [Accessed 11th July 2018].

[17] Park J, Kwon C, Son M. Economic implications of the Canada-U.S. border bridges: Applying a binational local economic model for international freight movements. Research in Transportation Business \& Management. 2014;11: 123-133. DOI: 10.1016/j.rtbm.2014.06.003 [Accessed 11th July 2018].

[18] Ord K. Estimation Methods for Models of Spatial Interaction. Journal of the American Statistical Association. 1975;70(349): 120-126. DOI: 10.2307/2285387 [Accessed 11th July 2018].

[19] LeSage JP, Fischer MM. Spatial econometric methods for modeling origin destination flows. WU Vienna University of Economic and Business, Vienna. 2008. Available from: http://epub.wu.ac.at/3957/ [Accessed 29th Jan 2019].

[20] LeSage JP, Peace RK (eds.) Spatial and Spatiotemporal Econometrics. New York, NY: JAI Press; 2004. DOI: 10.1016/S0731-9053(04)18013-4 [Accessed 29th Jan 2019].

[21] LeSage JP, Polasek W. Incorporating Transportation Network Structure in Spatial Econometric Models of Commodity Flows. Institute for Advanced Studies (IHS), Wien, Austria. Report number: 188, 2006. Available from: http://hdl.handle.net/10419/72305 [Accessed 29th Jan 2019].

[22] Arliansyah J, Taruna A, Rhaptyalyani, Kurnia AY. Needs Analysis of the Bridge Infrastructures Crossing over the Musi River of Palembang. Procedia Engineering. 2015;125: 438-444. DOI: 10.1016/j.proeng.2015.11.115 [Accessed 11th July 2018].

[23] Gumz F, Török Á. Investigation of Cordon Pricing in Budakeszi. Periodica Polytechnica Transportation Engineering. 2015;43(2): 92-97. DOI: 10.3311/PPtr.7579 [Accessed 25th Feb 2019].

[24] Anselin L. Spatial Econometrics: Methods and Models. Dordrecht, The Netherlands: Kluwer Academic Publishers; 1988.

[25] Varga A. Térökonometria. Statisztikai szemle. 2002;80(4): 354-370. Hungarian.
[26] Sarmiento-Barbieri I. An Introduction to Spatial Econometrics in R. In: Ninth Annual Midwest Graduate Student Summit on Applied Economics, Regional, and Urban Studies (AERUS), 23-24 April 2016, Urbana-Champaign IL. 2016. Available from: http://www. econ.uiuc.edu/ lab/workshop/Spatial_in_R.html [Accessed 11 th July 2018].

[27] Szabó Z, Török Á. Spatial Econometrics - Usage in Transportation Sciences: A Review Article. Periodica Polytechnica Transportation Engineering. 2019;48(2): 143-149. DOI: 10.3311/PPtr.12047 [Accessed 30th May 2019].

[28] Anselin L, Bera AK, Florax R, Yoon MJ. Simple diagnostic tests for spatial dependence. Regional Science and Urban Economics. 1996;26: 77-104. DOI: 10.1016/01660462(95)02111-6 [Accessed 10th Feb 2019].

[29] Bivand RS. Spatial Dependence: Weighting Schemes, Statistics and Models. Bergen, Norway: Norges Handelshøyskole; 2017.

[30] Bivand RS, Hauke J, Kossowski T. Computing the Jacobian in Gaussian spatial autoregressive models: An illustrated comparison of available methods. Geographical Analysis. 2013;45(2): 150-179.

[31] Bivand RS, Piras G. Comparing Implementations of Estimation Methods for Spatial Econometrics. Journal of Statistical Software. 2015;63(18): 1-36.

[32] R Core Team. A language and environment for statistical computing. Wien, Austria: R Foundation for Statistical Computing; 2017.

[33] Szabó Z, Török Á. Magyarország határátkelőinek térökonometriai elemzése [Evaluating the Hungarian Border Crossings from Spatial Econometric Point of View]. Közlekedéstudományi Szemle. 2018;68(4): 4660. DOI: 10.24228/KTSZ.2018.4.4 [Accessed 13th Sep 2018]. Hungarian.

[34] One Planet Mérnökiroda Kft. Az országos közutak 2015. évre vonatkozó keresztmetszeti forgalma. Budapest, Hungary: Magyar Közút Nonprofit Zrt.; 2016. Available from: https://internet.kozut.hu/kozerdeku-adatok/orszagos-kozuti-adatbank/forgalomszamlalas/ [Accessed 10th Dec 2020]. Hungarian.

[35] Slovenská správa ciest. Celoštátne Sčitanie Dopravy v Roku 2015. Bratislava, Slovakia: Slovenská správa ciest; 2016. Available from: http://www.ssc.sk/sk/cinnosti/rozvoj-cestnej-siete/dopravne-inzinierstvo/celostatne-scitanie-dopravy-v-roku-2015.ssc [Accessed 8th Nov 2018]. Slovakian.

[36] Hungartan Central Statistical Office. Detailed Gazetteer of Hungary. Budapest, Hungary: Hungartan Central Statistical Office; 2018. Available from: https://www.ksh. hu/apps/hntr.main [Accessed 8th Nov 2018].

[37] Danis J, Dolinayova A, Cerna L, Zitricky V. Impact of the Economic Situation in the Slovak Republic on Performances of Railway Transport. Periodica Polytechnica Transportation Engineering. 2018;47(2): 118-123. DOI: 10.3311/PPtr.11185 [Accessed 29th May 2020].

[38] Lakatos A, Mándoki P. Sustainability Analysis of Competition in Public Transport Systems: A Comparative Case Study in Hungary and Finland. Periodica Polytechnica Civil Engineering. 2020;64(2): 545-556. DOI: 10.3311/PPci.14824 [Accessed 2nd June 2020]. 
[39] Pupavac D, Maršanić R, Krpan L. Elasticity of Demand in Urban Traffic Case Study: City of Rijeka. Periodica Polytechnica Transportation Engineering. 2019;48(2): 173-179. DOI: 10.3311/PPtr.11750 [Accessed 29th May 2020].

[40] Saif MA, Zefreh MM, Torok A. Public Transport Accessibility: A Literature Review. Periodica Polytechnica Transportation Engineering. 2019;47(1): 36-43. DOI: 10.3311/PPtr.12072 [Accessed 6th Mar 2019].

[41] Lakatos A, Mándoki P. Analytical, Logit Model-based Examination of the Hungarian Regional Parallel Public Transport System. Promet - Traffic\&Transportation. 2020;32(3): 361-369. Available from: https://traffic.fpz. hr/index.php/PROMTT/article/view/3307 [Accessed: 18th Jun 2020].

[42] Stępniak M, Rosik P. The Role of Transport and Population Components in Change in Accessibility: The Influence of the Distance Decay Parameter. Networks and Spatial Economics. 2018;18(2): 291-312. DOI: 10.1007/ s11067-017-9376-8 [Accessed 25th Mar 2019].

[43] Hagget P, (ed.) Geography. A Global Synthesis. Harlow, UK: Pearson Education Limited; 2001.

[44] Limão N, Venables AJ. Infrastructure, Geographical Dis- advantage, Transport Costs, and Trade. The World Bank Economic Review. 2001;15(3): 451-479.

[45] Chita E, Drimili E, Gareiou Z, Milioti C, Vranna A, Poulopoulos S, Zervas E. Impact of Economic Crisis on Passenger Transportation - Case of Travelling to the Greek Mainland from Crete. Promet - Traffic\&Transportation. 2020;32(3): 347-360. DOI: 10.7307/ptt.v32i3.3255 [Accessed 18th June 2020].

[46] Auerbach F. Das Gesetz der Bevölkerungskonzentration. Petermanns Geographische Mitteilungen. 1913;59: 7476. German.

[47] Maddala GS. Introduction to Econometrics. $3^{\text {rd }}$ ed. Chichester, UK: John Wiley\&Sons Ltd; 2001.

[48] Ušpalytė-Vitkūnienė R, Šarkienė E, Žilionienė D. Multi-criteria Analysis of Indicators of the Public Transport Infrastructure. Promet - Traffic\&Transportation. 2020;32(1): 119-126. DOI: 10.7307/ptt.v32i1.3175 [Accessed 18th June 2020].

[49] Popović VD, Gladović P, Miličić M, Stanković M. Methodology of Selecting Optimal Fare System for Public Transport of Passengers. Promet - Traffic\&Transportation. 2018;30(5): 539-547. DOI: 10.7307/ptt.v30i5.2538 [Accessed 18th June 2020]. 